\title{
Russian Banking Sector Under the Influence of Fintech Innovations
}

\author{
Alena Zaborovskaya ${ }^{1,{ }^{*}}$ Kira Gruzdeva ${ }^{1}$ Marija Borzemska ${ }^{2}$ Elena Kniazeva $^{1}$ \\ Mikhail Klimenko ${ }^{1}$
}

${ }^{1}$ Department of Finance, Money Circulation and Credit, Ural Federal University, Ekaterinburg, Russia

${ }^{2}$ Department of Humanities, Latvian University, Riga, Latvia

*Corresponding author. Email: zaborovskaya.alena@bk.ru

\begin{abstract}
The article highlights the main changes and prospects for the development of the banking industry under the influence of the development of financial technologies, which largely determine the future of the banking sector, dictating new formats of interaction with customers. Financial technologies stimulate the direction of evolution of the market of banking products and services. In this regard, the main purpose of this article is to reveal the features of classification and development of banking innovations in Russia, as well as to identify the problems associated with their implementation. The article analyzes the current development of the banking system, the essence of banking innovations, classification of banking products, opportunities and prospects for innovation in the banking sector. The main conclusions of this work are the advantages and disadvantages obtained by all participants in this process.
\end{abstract}

Keywords: Banking system, Financial technologies, Banking innovations, Financial market, Biometrics, Fast payment system.

\section{INTRODUCTION}

Nowadays, the bank's adaptation to modern realities determines its place in the market. The dominant position is occupied by those credit organizations that actively introduce new products and services, focusing on a new consumer with a gadget. Just recently, most of the Russians have completely switched to non-cash payments with a plastic card. But now smartphones are gradually replacing bank cards as a means of payment. This is largely facilitated by the introduction and development of financial technologies.

At the moment, financial technologies are becoming increasingly popular, becoming an integral part of all types of financial services: lending, payments and transfers, savings, investment, insurance, and others, transforming business models and increasing their customer orientation. Various fintech solutions are implemented by both large financial organizations, such as banks, and highly specialized fintech companies that provide a limited list of services. This technological transformation of the financial market requires a change in the banking system and its reorientation to the modern client ${ }^{1}$.

The relevance of the conducted research is primarily due to the emergence and development of the term "fintech", which was previously considered a limited banking concept and denoted the strengthening of innovative technologies in the banking sector, which now includes a set of sectors of new technologies and financial services $[1$, p. 2066, 2, p. 59]. The main problem with defining fintech is its universality and the fact that this phenomenon is in an active stage of growth [3, p. 5]. This largely determines the degree of development of competition in the banking sector and serves as a kind of impetus to the introduction of banking innovations.

\footnotetext{
${ }^{1}$ Development of financial technologies. Retrieved from: https://cbr.ru/fintech/
} 


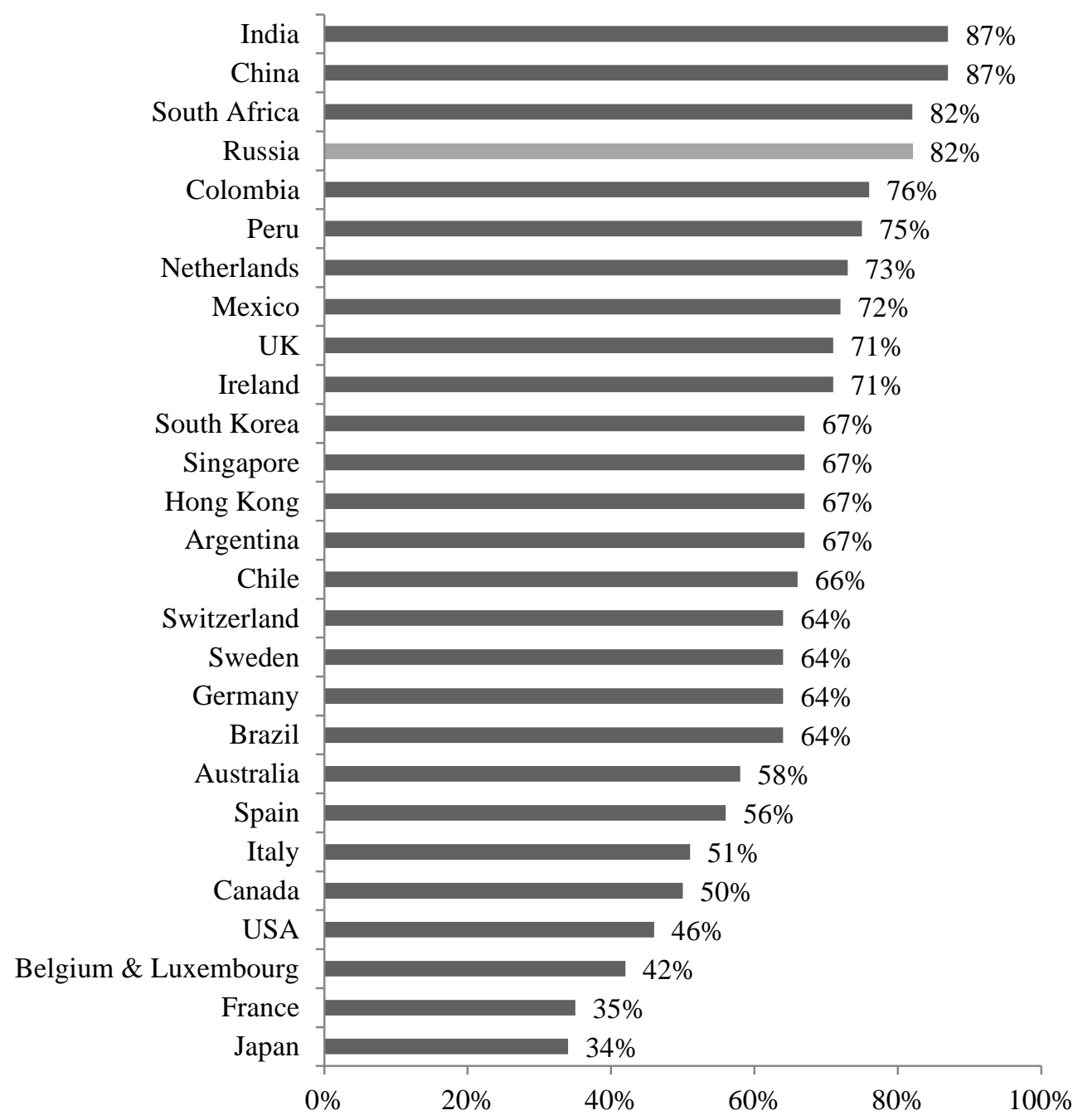

Figure 1 Share of fintech users from the online active population in 27 countries

\section{METHODOLOGY}

In the course of the research, such general scientific methods as description, analysis and synthesis, comparison, logical and system analysis, and graphical method of data representation were used.

To analyze the relationship between investments in innovative development of the banks and the size of their profits, a regression and correlation analysis was performed.

Correlation analysis was used to determine the forms and types of relationships, as well as their strength.

Regression analysis allowed us to determine the model parameters, statistical significance of the estimates, and check the adequacy of the model quality using the determination indicator, the value of which was estimated using the Fisher distribution tables. The Excel package was used for calculations.

The data sources were quarterly and annual profit and loss reports of the banks under study, published by the Central Bank of the Russian Federation.

\section{CURRENT DEVELOPMENT OF THE BANKING SYSTEM}

Today, many countries are implementing policies aimed at increasing people's access to financial services (financial inclusion), both at the national and international levels. Such inclusion (primarily the use of electronic transfers and payment cards) can become a driver of economic growth by democratizing investment instruments through mobile banking and 
reducing transaction costs, which will lead to an increase in household incomes [4, p. 26].

Fig. 1 shows the degree of financial technology penetration in 27 countries, including Russia ${ }^{2}$. Herewith, according to the data provided, the introduction of innovations in our country is at a fairly high level.

There are a number of trends, that form the prerequisites for stimulating and developing financial technologies, exist on the modern financial market of the Russian Federation, including ${ }^{3}$ : low marginality of the banking services; transformation of business models by financial market participants and the desire to create ecosystems [5, p. 7]; increasing the penetration of financial services through their digitalization [6, p.18, 7, p. 74]; loss by banks of monopoly on the provision of traditional (payment and other) services, as well as the acquisition by nonfinancial organizations of a significant role in the financial market; banks' aspiration to partner with startups and technology companies.

According to the research results, the most promising financial technologies are: Big Data and data analysis; mobile technologies [8, p. 27]; artificial intelligence [9, p. 284]; robotization [10, p. 1223]; biometrics; distributed registries [11, p. 11]; cloudbased technology.

The development of financial technologies is modernizing the traditional directions of banking amenities, where innovative products and services for end consumers are emerging.

\section{THE ESSENCE OF BANKING INNOVATIONS}

So, what is the repeatedly mentioned concept of "banking innovation"?

I. T. Balabanov considers that "banking innovation is the end result of a bank's innovative activity implemented in the form of a new banking product or operation", and innovative activity is understood as "a systemic process of creating and realizing innovations".

Approximately the same point of view is shared by many researchers in their research papers.

\footnotetext{
${ }^{2}$ EY Global Fintech Adoption Index 2019. Retrieved from: https://www.ey.com/en_gl/ey-global-fintech-adoption-index ${ }^{3}$ Main directions of financial technology development for the period 2018-2020 Retrieved from:

https://cbr.ru/Content/Document/File/85540/ON_FinTex_2017.pdf
}

According to O. I. Lavrushin, "banking innovation, or a set of new banking products and services - is a synthetic concept of the bank's activities aimed at generating additional income in the process of creating favorable conditions for the formation and placement of resource potential through the introduction of innovations that help customers make a profit." [12, p.39].

Thus, banking innovation constitutes the result of modernization or novation of banking products and services in order to meet the existing and emerging needs of the client in the process of managing the bank's resource potential.

The concept of banking technologies combines various subsystems of the bank related to information support, security, marketing and management, such $a^{4}$ : - software that provides daily implementation of current banking operations; - special computer programs designed to manage communications with clients, other banks, market partners, government and fiscal authorities; - elements of internal and external information security systems, databases, ATMs and self-service terminals, cash discipline and work of divisions in a modern bank; - internal procedures and models related to risk management; - electronic document management systems that link the processes of planning, organizing, and controlling activities and ensure continuous monitoring of performance discipline; - procedures and regulations that structure individual operations and product sales; - development of new customer service channels, etc.

Banking innovations must include all these processes in order to adapt to the modern financial market, maintain competitiveness and claim leadership in the industry.

Banking innovations are carried out covering: existing formal and interpersonal business processes written in the form of instructions, procedures, flowcharts or diagrams; - organizational structure, staffing and functional responsibilities of departments and employees involved in implementation; - software and hardware that serve to automate transactions and their accounting.

In this regard, in modern banking management, it is customary to distinguish the following types of banking innovations (Fig. 2).

\footnotetext{
${ }^{4}$ What is the difference between financial innovations and banking Retrieved from: https://viafuture.ru/katalog-idej/novyebankovskie-tehnologii
} 


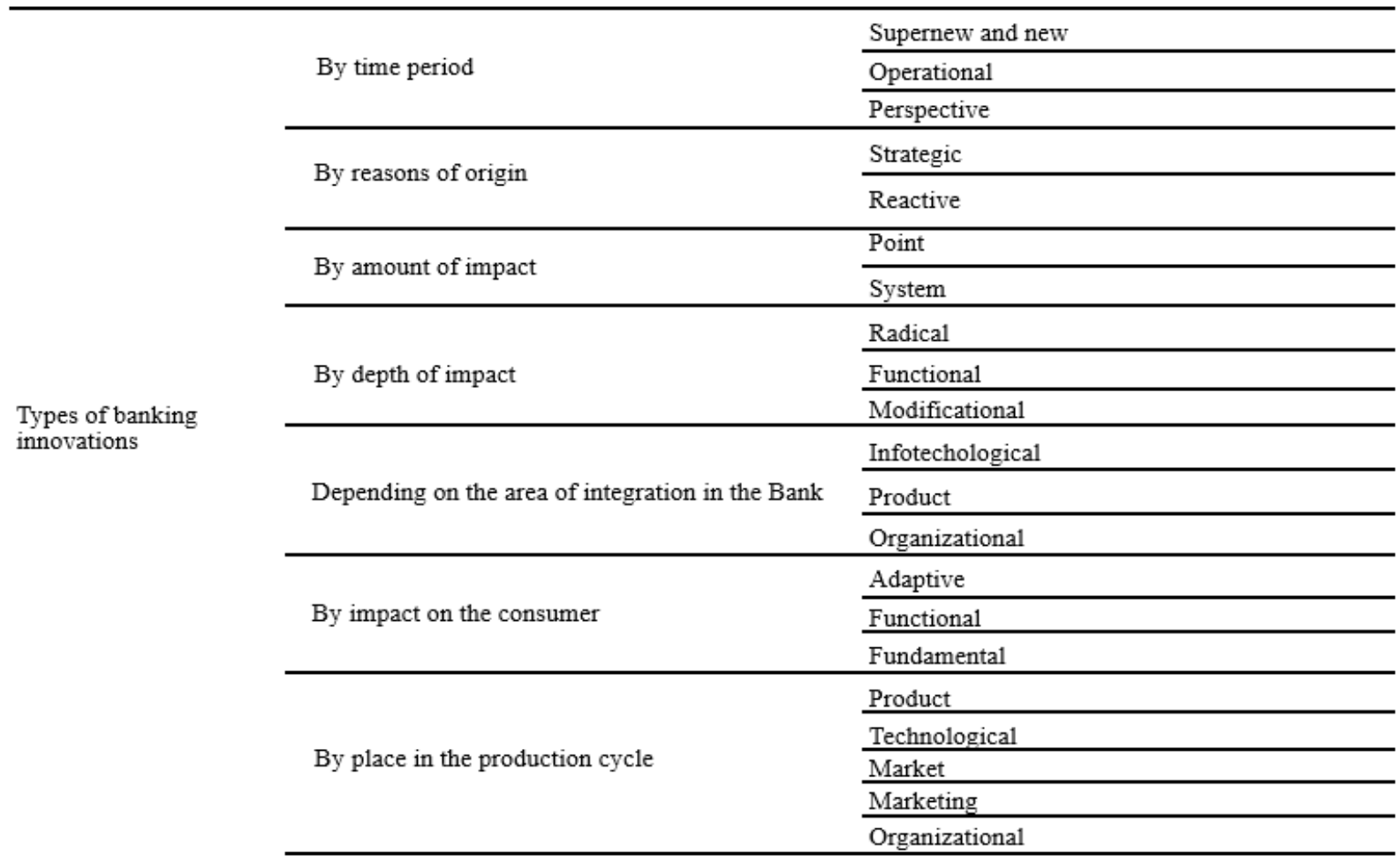

\section{Figure 2 Types of banking innovations $[13,14]$}

This classification makes it possible to effectively assess the policy in the field of conducting banking innovations, their performance as well as to identify some patterns of development and flow of innovation processes in credit institutions.

\section{DEVELOPMENT OF BANKING PRODUCTS}

Based on the information [15, 16], we will consider the chronology of the development of innovative bank activity in Russia and highlight the main trends and prospects for the development of banking innovations.

The first stage of development of banking innovations is considered to be the period from 1991 to 1997 , when banking activities were mainly related to settlement operations of legal entities, as well as operations with foreign currency. Despite hyperinflation and the economic crisis during the collapse of the Soviet Union, banks managed to make record profits without making financial investments. As a result, credit organizations did not think about increasing customer focus, and their investment activities were limited to the development and implementation of products and services that serve settlements.

The second stage of development of banking innovations in the Russian Federation falls on the period 1998-2001 and is considered to be transitional due to the recovery of the consequences of the financial crisis throughout the country. Banking innovations were directed to the real sector of the economy and working with clients, which was necessary due to the fall of financial markets.

The third stage of development of innovations in the banking sector in the period from 2002 to 2007 can be called a time of intensive development of bank innovative activity. During these years, the Russian economy has been steadily growing and the quality of life of the population has improved. The predominant direction of banking innovations has become their focus on retail credit products.

The fourth stage is in 2008-2012. This time is considered the period of recovery of the Russian economy after the global financial crisis. The main focus is on creating favorable conditions for increasing the level of competition and eliminating financial illiteracy of the population.

The fifth stage of the development of banking innovations began in 2013 and continues at the present time. For the Russian economy, this period was marked by the currency crisis of 2014-2015, which effectively closed the access of Russian banks to the foreign financial market. Against this background, it became necessary to attract more resources from residents. 
Therefore, artificial intelligence, machine learning and other advanced technologies and practices have helped banks to improve the overall quality of management, get real-time forecast data, and work faster and more efficiently.

The global pandemic of 2020 gave a special impetus to the digital transformation of the banking sector. The

self-isolation regime allowed banks to actively bring services and digital products to a new level. This is due to the emergence of modern banking technologies and innovations. Among them, we can highlight the rating of technical banking innovations that appeared in $2019^{5}$ (tab. 1).

We can conclude that all the above-mentioned banking innovations are based primarily on the fast payment system and a single biometric system that allow you to recognize a person and instantly perform many banking operations, including: money transfers, payments, cash withdrawals, and in the future, the issuance of consumer loans.

\section{Table 1. Top 10 banking innovations of 2019}

\begin{tabular}{|c|c|c|}
\hline $\begin{array}{l}\text { Place in } \\
\text { rating }\end{array}$ & $\begin{array}{l}\text { Type of } \\
\text { innovation }\end{array}$ & Characteristic of innovation \\
\hline 10th place & $\begin{array}{l}\text { Payment of the } \\
\text { ring. } \\
\text { Rosselkhozbank }\end{array}$ & $\begin{array}{l}\text { The NFC ring allows you to pay for purchases without using additional means of } \\
\text { payment (bank card or mobile app). Rosselkhozbank offers a different design of these } \\
\text { rings (it became available in January 2019), as well as a new mobile application "Easy } \\
\text { front", which allows you to activate the ring anywhere in the country without visiting } \\
\text { the office. }\end{array}$ \\
\hline 9th place & $\begin{array}{l}\text { Maps with } \\
\text { augmented } \\
\text { reality. } \\
\text { Gazprombank }\end{array}$ & $\begin{array}{l}\text { At the Finopolis-2019 forum Gazprombank presented plastic cards with augmented } \\
\text { reality technology. By installing a new version of the mobile Bank on your smartphone } \\
\text { and pointing the camera at the "plastic", you can see a colorful "cartoon", which can } \\
\text { help increase loyalty to the Bank. }\end{array}$ \\
\hline 8th place & $\begin{array}{l}\text { ATM without a } \\
\text { card. Alfa-Bank }\end{array}$ & $\begin{array}{l}\text { In many ATMs (not only Alfa-Bank), you can now withdraw money without a card, } \\
\text { using only a smartphone with a mobile app (it is enough to have an NFC reader on the } \\
\text { ATM). But the new Alfa-Bank device does not have a card slot at all, and paper checks } \\
\text { are not printed. It is assumed that this will increase the speed of cash withdrawal } \\
\text { operations by half. However, such ATMs are available in a limited number of regions } \\
\text { where the Bank operates. }\end{array}$ \\
\hline 7th place & $\begin{array}{l}\text { Payment by QR } \\
\text { code. Sberbank }\end{array}$ & $\begin{array}{l}\text { Sberbank was the first to provide the opportunity to pay for goods in stores using a } \\
\text { QR code. However, the convenience of such a service is not obvious, since in order to } \\
\text { pay for a product or service, you must first download the mobile app, and then select } \\
\text { the "Pay QR" option, although it is easier to get a contactless card and pay with one } \\
\text { touch. }\end{array}$ \\
\hline 6th place & $\begin{array}{l}\text { Virtual mortgage } \\
\text { (VR-mortgage). } \\
\text { VTB }\end{array}$ & $\begin{array}{l}\text { VTB launched a VR mortgage service in June 2019. It is now available to residents of } \\
\text { four Russian cities, including Yekaterinburg. Wearing glasses, a person can view the } \\
\text { apartments available in the database, their design options, as well as the location of } \\
\text { the house on the city map and the surrounding infrastructure (schools, hospitals, } \\
\text { playgrounds, transport stops). At this time, the virtual consultant talks about the } \\
\text { characteristics of the object and the conditions of a possible mortgage loan. }\end{array}$ \\
\hline 5th place & $\begin{array}{l}\text { Virtual vision. } \\
\text { Sberbank }\end{array}$ & $\begin{array}{l}\text { At the Finopolis 2019, Sberbank demonstrated new speech and biometric technologies } \\
\text { that can be used for pass systems in buildings. The scanner takes a biometric image of }\end{array}$ \\
\hline
\end{tabular}

${ }^{5}$ TOP-10 banking innovations of 2019. Retrieved from: 


\begin{tabular}{|c|c|c|}
\hline & & $\begin{array}{l}\text { a person at the entrance, identifies it and transmits all the data to the operator's } \\
\text { computer. }\end{array}$ \\
\hline ace & $\begin{array}{l}\text { Cash withdrawal } \\
\text { at the checkout. } \\
\text { Sberbank, } \\
\text { Raiffeisenbank }\end{array}$ & $\begin{array}{l}\text { When paying with a bank card, you can additionally cash out up to 5,000 rubles. The } \\
\text { relevance of the service is obvious, and in a recent survey conducted by } \\
\text { Raiffeisenbank, } 60 \% \text { of respondents said that they are interested in this service. } \\
\text { The technology has not yet been implemented in the Urals. In the capital region, the } \\
\text { process has started and there are already stores that issue cash from the card at the } \\
\text { checkout: for example, Vkusvill-withdrawals using Sberbank cards, BILLA-withdrawals } \\
\text { using Raiffeisenbank cards. }\end{array}$ \\
\hline $3 r d p$ & $\begin{array}{l}\text { Issuing consumer } \\
\text { loans using } \\
\text { remote biometric } \\
\text { identification. } \\
\text { Promsvyazbank }\end{array}$ & $\begin{array}{l}\text { Remote identification is a mechanism that allows individuals to receive financial } \\
\text { services remotely from different banks by verifying their identity using biometric } \\
\text { personal data (face image and voice). } \\
\text { Creating and developing a platform for remote identification allows you to transfer } \\
\text { financial services to a digital environment, increase the availability of financial services } \\
\text { for consumers, including people with disabilities, the elderly and the low-mobilited, } \\
\text { and increase competition in the financial market. }\end{array}$ \\
\hline 2nd & $\begin{array}{l}\text { Fast payment } \\
\text { system. Payment } \\
\text { for goods with a } \\
\text { QR code. SKB- } \\
\text { Bank }\end{array}$ & $\begin{array}{l}\text { SKB-Bank has implemented the full functionality of paying c2b (individual - legal entity) } \\
\text { using a QR code through a quick payment System with the possibility of a refund. } \\
\text { To pay for the product using a QR code, the buyer must have a phone with the bank's } \\
\text { mobile app connected to the fast payment system. You need to turn on the phone's } \\
\text { camera, point at the QR code, then everything happens automatically - the mobile app } \\
\text { is loaded, the amount is entered, and the buyer just needs to click the " pay " button. }\end{array}$ \\
\hline 1st place & $\begin{array}{l}\text { Biometric } \\
\text { payment. "Russkiy } \\
\text { Standart" Bank. }\end{array}$ & $\begin{array}{l}\text { This is, in fact, an attempt to combine biometrics and a fast payment system. To pay } \\
\text { for the product at the checkout, just select the payment method and confirm the } \\
\text { payment by looking at the camera. No phones or cards are required. }\end{array}$ \\
\hline
\end{tabular}

\section{RESULTS}

To determine the banks' expenses, spending on innovation, refer to the Fig. 3. The main share of research and development expenses for banking innovations in 2019 is in the organizational and management expenses of SKB-Bank, which launched a new Internet banking platform "SKB Online" in 2018. The second place in terms of the share of expenses for banking transformations is occupied by Raiffeisenbank, which was recognized as the most digital bank in Russia in $2019^{6}$. In addition, we can note a significant increase in the innovative potential of VTB Bank.

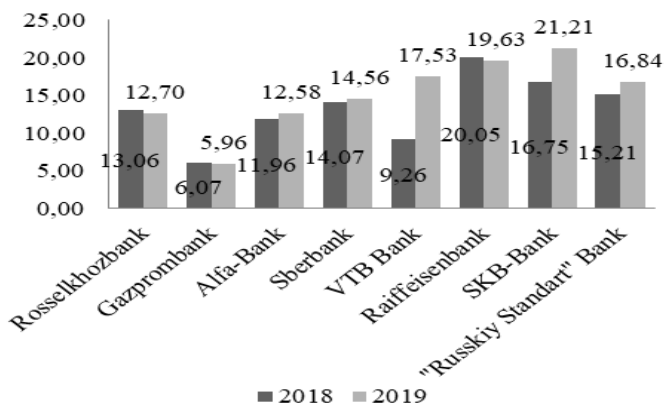

Figure 3 Share of expenses on banking innovations in organizational and management expenses of banks in Russia.?

To analyze the relationship between investments in innovative development of the banks shown in Fig. 3 (with the exception of Sberbank, whose performance parameters may introduce serious errors in the

\footnotetext{
${ }^{7}$ Reports on financial results (form 102, quarterly) of banks for 2018 and 2019. Retrieved from: https://cbr.ru/banking_sector/credit/

${ }^{6}$ Raiffeisenbank is recognized as the most digital Bank in Russia by the end of 2019. Retrieved from: https://www.raiffeisen.ru/about/press/releases/128390/
} 
calculations) and the size of their profits ${ }^{8}$, a regression and correlation analysis were carried by authors (Fig. 4).

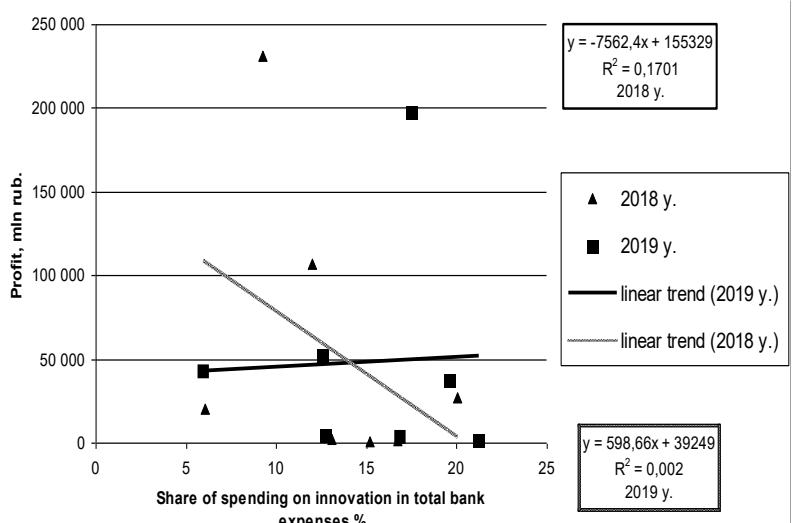

Figure 4 Dependence of the amount of the received profit on the share of innovation expenses in the total expenses of banks.

Correlation analysis, , was used to determine the forms and types of relationships, as well as their strength. The graphical method (the nature of the location of points corresponding to the intersection of factor and result features in the correlation field) allows to clearly understand the nature (shape and direction) of the relationships. A linear relationship was found, since the function approximating changes in the mean is also linear.

Regression analysis allowed us to determine the model parameters, statistical significance of the estimates, and check the adequacy of the model quality using the determination indicator, the value of which was estimated using the Fisher distribution tables. The Excel package is used for calculations. Correlation coefficients ( $\mathrm{r}$ ) and determination coefficients $\left(\mathrm{r}^{2}\right), \%$, are determined, and linear regression equations are constructed (tab. 2).

When considering the relationship of indicators in 2018, an inverse, not very close relationship was revealed. In other words, when the share of innovation expenditures increased, there was no increase in profit. At the same time, it is highly likely that this is not due to the need for such expenses, but rather to their rather long payback period. But in 2019, the connection becomes direct, but still very weak. And we can already assume that if the share of spending on innovation increases by $1 \%$, the banks' profit may increase by about $600 \mathrm{mln} . \mathrm{rub}$
Table 2. Quantitative criteria for evaluating the relationships of empirical data for 2018-2019 yy.

\begin{tabular}{|c|c|c|c|}
\hline Index & 2018 & Index & 2019 \\
\hline $\begin{array}{c}\text { Correlation } \\
\text { coefficient }(r)\end{array}$ & $-0,41$ & $\begin{array}{c}\text { Correlation } \\
\text { coefficient }(r)\end{array}$ & 0,05 \\
\hline $\begin{array}{c}\text { Determination } \\
\text { coefficient } \\
(\mathrm{r} 2), \%\end{array}$ & 0,17 & \begin{tabular}{|c} 
Determination \\
coefficient \\
$(\mathrm{r} 2), \%$
\end{tabular} & 0,002 \\
\hline $\begin{array}{l}\text { Linear } \\
\text { regression } \\
\text { equation }\end{array}$ & $\begin{array}{r}y=155329 \\
7542,6 x\end{array}$ & $\begin{array}{l}\text { Linear } \\
\text { regression } \\
\text { equation }\end{array}$ & $\begin{array}{c}y=39249+ \\
598,66 x\end{array}$ \\
\hline
\end{tabular}

\section{CONCLUSION}

The main advantages of implementing innovative technologies and a unified biometric system include: improving the quality of the loan portfolio by reducing delays in loan repayments; increasing the bank's income and profit [22]; increasing the number of customers who use banking services [23]; accurate and objective identification of borrowers.

At the level of a simple user, the introduction of financial innovations saves time, eliminating participation in a variety of processes, and guarantees economic security of activities, since all innovative financial products and services are technically protected by the most modern instruments of electronic protection.

The disadvantages of introducing financial innovations include: the high cost of innovative products; the lack of a legal framework; the lack of sensitivity to innovations on the part of financial market participants; the lack of development of innovation infrastructure; information inequality of various market participants.

In addition, the introduction of innovative transformations reduces the need for labor, as customers using Internet banking reduce their stay in territorial offices and branches.

Despite this, the implementation of innovative changes in the banking sector leads to the achievement of such key goals as: improving the competitiveness of the Russian banking system; creating a dynamic model for the development of the banking sector based on knowledge; reduced staff employment in front offices; providing temporary optimization of banking operations; improvement of the state of banking

\footnotetext{
${ }^{8}$ Reports on financial results of banks for 2018 and 2019.

Retrieved from: https://cbr.ru/banking_sector/credit/
} 
services in General (increase in profitability and efficiency).

However, any changes in the banking sector involve significant risks. Within the framework of innovative banking, the following risk factors are identified:

- macroeconomic (including the financial crisis, inflation, changes in the effective demand of the population, currency depreciation, changes in interest rates);

- personnel (low level of qualification of employees, the risk of leakage of insider information);

- technological (include low automation, integration of the latest electronic technologies with more outdated information systems, integration of new organizational structures with accumulated databases and business processes);

- financial (underfunding of innovative projects, closing of budgets);

- management (inconsistency of innovative activities);

- competitive (the probability that a competitor will have a similar banking product or service);

- criminal (fraud in the field of innovation banking).

Therefore, it is very important for the prospects of applying and implementing banking innovations:

- create and apply unique banking products and services as part of the development of modern information technologies;

- provide complete information about new products and services to the end user in order to increase customer demand for banking innovations;

- increase the level of security of information and its transmission channels;

- improve the level of qualification of the Bank's employees in the field of innovation development;

Thus, financial innovations play a leading role in the formation and accelerated development of the financial market in Russia. Financial innovations allow Russian banks to rationalize and improve the quality of banking services, thereby creating competitive advantages not only for a number of individual banks, but also for the entire banking system as a whole.

\section{AUTHORS' CONTRIBUTIONS}

Alena Zaborovskaya and Kira Gruzdeva conceived of the presented idea. Alena Zaborovskaya developed the theoretical formalism, performed the analytic calculations and performed the numerical simulations. Alena Zaborovskaya encouraged Kira Gruzdeva to investigate the types of banking innovations in Russia and supervised the findings of this work. Marija Borzemska and Mikhail Klimenko verified the analytical methods. Elena Kniazeva revised the article it critically for important intellectual content. All authors provided critical feedback, helped shape the research, analysis and manuscript and discussed the results and commented on the article.

\section{REFERENCES}

[1] Mark A Chen, Qinxi Wu, Baozhong Yang, How Valuable Is FinTech Innovation?, in: The Review of Financial Studies 32(5) 2019 2062-2106. DOI: https://doi.org/10.1093/rfs/hhy130

[2] Anne-Laure Mention, The Future of Fintech, in Research-Technology Management 62(4) (2019) 59-63.

DOI: https://doi.org/10.1080/08956308.2019.1613123

[3] Ramona Rupeika-Apoga, Inna Romānova, Simon Grima. FINTECH STUDY LATVIA 2020, 2020. DOI: 10.13140/RG.2.2.33222.09285/1

[4] Belozyorov S., Sokolovska O., Kim Y, Fintech as a Precondition of Transformations in Global Financial Markets, Foresight and STI Governance 14(2) (2020) 23-35. DOI: 10.17323/2500-2597.2020.2.23.35 (In Rus.)

[5] Kleiner G.B., Rybachuk M.A., Karpinskaya V.A., Development of ecosystems in the financial sector of Russia. Upravlenets - The Manager 11(4) (2020) 2-15. DOI: 10.29141/2218-50032020-11-4-1. (In Rus.)

[6] Akatkin Y.M., Karpov O.E., Konyavskiy V.A., Yasinovskaya E.D., Digital economy: Conceptual architecture of a digital economic sector ecosystem, Business Informatics 4 (42) (2017) 17-28. DOI: 10.17323/19980663.2017.4.17.28.

[7] Kotliarov I.D., Digital transformation of the financial industry: The substance and trends. Upravlenets - The Manager, 11(3) (2020) 72-81. DOI: 10.29141/2218-5003-2020-11-3-6. (In Rus.) 
[8] Belousova V., Chichkanov N., Mobile Banking in Russia: User Intention towards Adoption. Foresight and STI Governance 9(3) (2015) 2639. DOI: $10.17323 / 1995-459 x .2015 .3 .26 .39$ (In Rus.)

[9] Chernov, V. A., Implementation of Digital Technologies in Financial Management. Ekonomika regiona [Economy of region] 16(1) (2020) 283-297. DOI: 10.17059/2020-1-21 (In Rus.)

[10] Maslennikov, M. I., The Technological Innovations and their Impact on the Economy. Ekonomika regiona [Economy of region] 13(4) (2017) 1221-1235. DOI: 10.17059/2017-4-20 (In Rus.)

[11] Sukhodolov A.P., Beryozkin Yu.M., From the Institutional to the Platform Economy. Upravlenets - The Manager 9(3) (2018) 8-13. DOI: 10.29141/2218-5003-2018-9-3-2.

[12] Antufiev A. G., Tabachny E. M. Innovations in the banking sector, Science and education today, 5(40) (2019) 39-40. (In Rus.)

[13] Usova N. V., Types of banking innovations and their role in improving the competitiveness of banks, in: Proceedings of the International Scientific-practical conference «Theoretical, methodological and practical problems of integration», Samara, ANPO "Publishing house SNTC”, 2018, pp. 236-241. (In Rus.)

[14] Prosalova V. S., Nikitina A. A., Banking concept of innovations and their classification, Science of science, 1(14) (2013) Identification number of the article in the journal: 40EVN113 (In Rus.)

[15] Gorlovoy D. N. Trends in the development of banking innovations in the Russian Federation, Vector of the economy 4 (46) (2020) 47-54 (In Rus.)

[16] Zinovieva N. M., Yurina N. V. Banking innovations in Russia at the present stage of development, Territory of science 3 (2016) 7680. (In Rus.)

[17] Vasilenko O. A., Trends and prospects of development of financial innovations in the banking business of Russia, The world of the new economy vol. 13 (2) (2019) 80-89. https://doi.org/10.26794/2220-6469-2019-13-280-89 (In Rus.)
[18] Fedosenko A.V., Gudkova O. V., Ermakova L. $\mathrm{V}$. Innovations in banking: advantages and disadvantages, in: Trends and prospects for the development of the banking system in modern economic conditions: materials of the II international scientific and practical conference, Bryansk, 2020, pp. 253-257. (In Rus.)

[19] Tarkhanova Elena, Chizhevskaya Elena, Baburina Natalia, Institutional changes and ditigalization of business operations in financial institutions, Journal of institutional studies 10(4) (2018) 145-155. DOI: $10.17835 / 2076-$ 6297.2018.10.4.145-155

[20] Gavryushina D. B., Risks of banking innovations and their consideration in the prevention of banking crises, in: Topical issues of economic Sciences and modern management: a collection of articles based on the materials of the $\mathrm{V}$ international scientific and practical conference, Novosibirsk, SibAK, 2017, pp. 6-10. (In Rus.)

[21] Gorlovoy D.N., Maziy V.V., Banking innovations: prospects and problems of implementation, The Eurasian Scientific Journal [online] 1(12) 2020.

[22] Zhuo JW, Li Xinmiao, Yu Changrui, How to Integrate Financial Big Data and FinTech in a Real Application in Banks: A Case of the Modeling of Asset Allocation for Products Based on Data. Information 11(10) 2019460. DOI:10.3390/info11100460.

[23] Mejia-Escobar JC, Gonzalez-Ruiz JD., DuqueGrisales E., Sustainable Financial Products in the Latin America Banking Industry: Current Status and Insights. Sustainability. 12(14) 20205648. DOI: https://doi.org/10.3390/su12145648. 